\title{
ПРИНЦИПИТЕ НА МАГИЈАТА ВО РАЗБИРАњЕТО НА ПОТЕКЛОТО НА РЕЛИГИЈАТА
}

\section{Кратика сооржина}

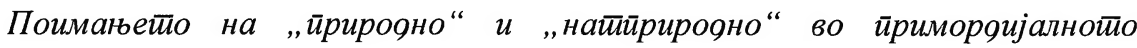

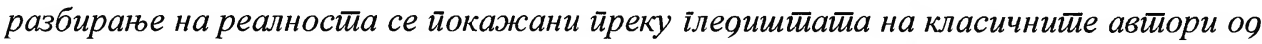
иолетио на йеориитете за йойеклойо и за ирирояайа на релиіијайа (Тајлор, Фрејзер, Диркем, Џевонс ийн.). Сфакањетио на (най)ирироониие сили и верувањетоо во онйолоики ооминанйно йосииоее на архаичниие релиіиозни луіе йойоа се ирикажани како ирринцийи иреку кои нивниие верувања за нивнайа врска со светиой и йозичијата во неіо можай gа бияай резимирани. Иоеийе gека hoто religiosus, иреку серии ритиуални яејстива, иеемелно йланирани и ирецизно конйролирани, има

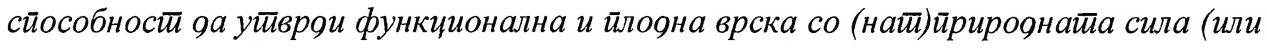

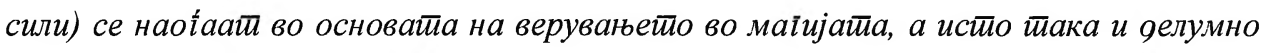
во ранийе форми на релиіија. Поенйайа и челийе на сериитее на маіискииее

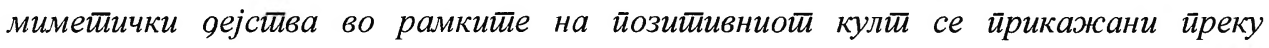
резимеайа на Фрејзер и Мос и Убер, и иреку сличносииите и разликиие меtу

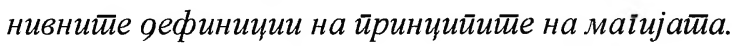

\section{Клучни зборови: МАГИЈА, (НАТ)ПРИРОДНО, РЕЛИГИОЗЕН ЧОВЕК, РИТУАЛ, ПРИНЦИП}

Идејата за „натприродното“ во примордијалните заедници

Во време во кое светот ни е познат и близок, а природните појави што до скоро предизвикувале зачуденост и стравопочит во голема мера разјаснети, омаѓепсаноста на светот се губи, како што се губи и верувањето во светото како супериорна стварност за верникот. Додека чувството на светото, сепак, се одржува низ интензивни чувства на возвишена трогнатост или проникнувачка свесност за поврзаност со нешто што ги надминува параметрите на секојдневното постоење, чувствата на омаѓепсаност од светот и верувањето дека поседуваме моќ директно да интервенираме врз светот се губат. А, сепак, додека ни се познати причините за грмотевиците и вулканските ерупции, непознати остануваат обемни сфери од областа на квантната физика и на медицината. Колку и да е анимизмот одамна надминат, негодуваме и се расправаме кога компјутерите и машините се „непослушни“, се обидуваме печатачот да не „дознае“ дека брзаме, ги „прашуваме“ интернет-пребарувачите. Технологијата се развива толку брзо што начините на функционирање едвај разбирливи пред дваесетина години сѐ повеќе се земаат како нешто „дадено“, нешто што ја олеснува стварноста и предизвикува чувство на доминантност врз 
неа. ${ }^{1}$ Технологијата се развила за да престанеме да се потпираме на магиските начини на мислење и дејствување. А всушност, технологијата е таа преку која светот повторно се омаѓепсува. Во понатамошниот текст кратко ке бидат изложени принципите на магијата од областа на теориите за потеклото на религијата.

Според Едвард Тајлор (Edward Tylor), претставник на англиската антрополошка школа и застапник на анимистичката теорија, она што кај примитивните народи бил обичајот, се зачувало кај поцивилизираните како траги од минатото. На тој начин се забележува сличноста на начините на мислење и на постапување. За Тајлор тие се строго рационални, но лимитирани од историските околности. Не може да се зборува за примитивен ум, иако се зборува за примитивна култура, затоа што нема разлика меѓу умот на примитивниот и на цивилизираниот човек, се работи за разлики во историското искуство. Примитивниот човек на сосема рационален, промислен и стабилен, дури и логички начин размислувал за светот и ја создавал митологијата, постојано обидувајќ се да ги разреши прашањата во врска со фактите и појавите што не можел да си ги објасни, постојано обидувајќи се да ја сфати смислата на она кое го опкружува. ${ }^{2}$

На слична линија со Тајлор во врска со природата на примитивното мислење се наоѓа Џејмс Џорџ Фрејзер (James George Frazer). ${ }^{3}$ Човекот кој изведува магиски обреди не се разликува од научникот кој изведува експерименти во својата лабораторија, затоа што обајцата го следат правилото на каузалитетот. Во таа смисла, светот на науката и светот на магијата се мошне блиски - ова е мошне познатиот став на Фрејзер. Жрецот на примитивните племиња и модерниот научник, смета тој, се водат по исти принципи. Кога симпатетичката магија (чии два главни принципа се принципот на сличност и принципот на контакт, и кои можат да се сведат на верување во принципот на симпатетичко дејство на условување, од каде што е и употребата на терминот), се јавува во чиста и непроменета форма, таа тргнува од претпоставката дека во природата настаните следуваат едноподруго, непроменливо и нужно, без да им се влијае на каков било начин. Таквото сфаќае е исто со она на модерната наука и верата во редот и еднообразноста на природата. Според законот на каузалитетот (односно, навиката или обичајот), жрецот, или оној што се занимава со магиски дејства (маг, шаман, врач, волшебник), не се сомнева дека исти причини секогаш даваат исти последици. Во ова магијата и науката се сосема слични: обете се потпираат на

\footnotetext{
' Во оваа смисла, авторот на научна фантастика Артур Кларк (Arthur Clarke) го формулира својот трет закон за предвидување со „која било доволно напредна технологија не може да биде разликувана од магија“ (ревидиран го наведува во делото "Hazards of Prophecy: The Failure of Imagination", 1973). Исак Асимов (Isaac Asimov) во својот серијал Foundation поставува ситуација во која научниците кои манипулираат со нуклеарната енергија се претставени пред народот како да имаат магиски моќи и речиси божествено раководат со стварноста, тие се атомско свештенство (така се развива „скентизмот“ или „црквата на науката“).

${ }^{2}$ Така, разликата меѓ најсировите форми на анимизам и најразвиените филозофски и теолошки системи е само во степенот на развиеност на поимната и операционалната апаратура - тие имаат иста почетна точка и ист предмет, обидувајки се да ги објаснат егзистенцијалните проблеми, но различна методологија (Е. В. Tylor, Primitive Culture (Researches Into īhe Development of Mythology, Philosophy, Religion, Language, Art And Custom), Vol. II, Henry Holt and Company, New York 1874, ch. 12).

${ }^{3}$ На Емил Дирекм (Emile Durkheim) му пречи ова: тој го критикува Фрејзер за тоа што не успеал да го препознае длабоко религискиот карактер на верувањата и ритуалите на примордијалните заедници, туку смета дека мислата нема никаква важна разнородност, туку останува секогаш иста, од првите рудиментирани чекори до највисоките достигнувања.
} 
тоа дека редоследот на настаните е правилен и извесен, определен од фиксни закони, а неочекуваноста и чудата од тоа се исклучени, освен ако не се работи за „чуда“ контролирани од оние што дејствуваат. Проблемот на магијата, смета Фрејзер, не се состои во тоа што таа греши во основните претпоставки дека редоследот на настаните е одреден со закони, туку во тоа што не ја разбира природата на посебните закони што владеат со тој редослед. На тој начин магиските ритуали, всушност, се резултат на погрешна примена на основни закони на мислењето, односно на асоцијацијата на поимите по сложеност и по просторно-временската сукцесивност. Затоа и погрешноста на магиските принципи може да се сведе на верувањето дека ако нешто следува по нешто друго, тоа е и причинето од тоа, или принципот „ако по нешто, тогаш и поради/како резултат на тоа нешто“ - post hoc, ergo, propter hoc. Така, кога асоцијативните закони се применуваат правилно - создаваат наука, а кога се применуваат неправилно - создаваат магија, која е незаконската сестра на науката, смета Фрејзер. Идејата за интервенцијата врз стварноста, пак, е потполно иста.

Диркем верува дека идејата за природните сили веројатно е произлезена од идејата за религиски сили и дека не може да има остра граница меѓу рационалното и нерационалното. Тоа што религиските сили често се замислуваат како духовни суштества или свесни волји не е доказ за нивната нерационалност. Разумот не е a priori отпорен на идејата дека тела без душа можат да бидат движени од интелигенции, како човечките тела, иако во современата наука и нема место за оваа хипотеза. ${ }^{5}$ Идејата за натприродното е скорешна, затоа што претпоставува свесност за идејата за природен ред, настојува Диркем. Мора да има принципи за релациите меѓу феномените, за да може да има идеја за нарушување на тие принципи. Идејата за универзален детерминизам е со доцно потекло, дури и најголемите мислители од класичната антика немале полна свесност за неа. Таа идеја е типична за емпириските науки - постулат на кој се потпираат и кој нивниот развој го има докажано. Но, недостигот од принципот создава и недостиг од неговата спротивност. Чудесните интервенции што им биле припишувани на божествата во антиката не биле сметани за чуда во модерната смисла на зборот. За нив тие биле убави, или возвишени, или чудни, или ужасни објекти на изненадување и чудење, но не како увид во мистериозен свет во кој разумот не би можел да навлезе. Не религијата, туку науката, инсистира Диркем, ги има научено луѓето дека светот е комплексен и тежок за разбирање. Но, Диркем наведува дека, според Френк Бајрон Џевонс (Frank Byron Jevons), човечкиот ум нема потреба од систематично научно образование за да забележи дека постојат дефинирани секвенции и постојан ред на сукцесивност на феномени, ниту дека ваквиот ред е често нарушуван. На овие случувања им биле припишувани натприродни причини затоа што се надвор од вообичаениот ред на настаните. Џевонс тврди дека идејата за натприродното е на почетокот на историјата и дека токму преку неа религијата го има добиено својот карактеристичен објект, со што Диркем не се согласува.

\footnotetext{
${ }^{4}$ J. G. Frazer, The Golden Bough: A Study in Magic and Religion (Electronic version Wordwordth, London, 1890), The Floating Press, 2009, p. 124.

${ }^{5}$ É. Durkheim, Les formes élémentaires de la vie religieuse, PUF, Paris, 1968, p. 36.
} 
Според Џевонс, тврдењето за иницијално верување во натприродното припаѓa на историјата на религиите, додека неговата валидност припаѓ на филозофијата на религијата. ${ }^{6}$ Џевонс ги определува „современите“ докази, како сказните создадени во раниот период на човековата раса, на пример, како добри индикатори за тоа како било кога „...природата имала само неколку закони да почитува, а и нив не ги почитувала униформно“, за што доказ е фактот дека за примитивните луѓe кои сѐ уште функционираат инцидентите од сказните кои на непримитивните модерни луѓе им се чинат чудесни и натприродни се прашања на вообичаено, дури секојдневно случување. ${ }^{7}$ Џевонс смета дека додека модерниот човек му ја должи својата наука и удобноста на примитивниот човек, примитивниот човек ја должи својата одржливост во неговите опасни околности на дарот од моќта со која човештвото ја освоило материјалната вселена. Тој дар е ,..верата во униформноста на природата, верувањето дека она кое се има случено во слични околности повторно ќе се случи“. Ова е очигледно во историјата на религиите, според Џевонс, а кога не би било, преку ставот или дека за него сѐ било натприродно или дека ништо не било натприродно, би се направила грешката на замислување дека постоело време во кое човекот не правел дистинкција меѓу природното и натприродното. Така, кога не постојат природни закони, не постои ни свесност за нужни врски - со недостатокот на концепцијата на природното недостасува и идејата за натприродното. Интересно е што Џевонс веднаш ја дава спротивната опција: според ова гледиште, кога не се познати природните закони, не може да има природна и нужна врска меѓ настаните и затоа сѐ е натприродно. Така, според ова гледиште, излегува дека примитивниот човек живеел во состојба на постојано изненадување, зачудувајќки се секој пат кога ќе откриел вообичаени факти, како што е, на пример, дека водата е мокра. Ова гледиште е мошне неверојатно за Џевонс и мора да биде отфрлено. ${ }^{8}$

Во својата анализа на англиската антрополошка школа и третманот на религијата на Џевонс, Марсел Moc (Marcel Mauss) од француската социолошка школа нагласува дека Џејмс Фрејзер гледа извесно совпаѓање на примитивната религија и симпатетичката магија, што се наоѓa во фолклорот. Тие имаат исто потекло, затоа што обете потекнуваат од иста концепција за природата, во која не постои ни поимот за природното ни поимот за натприродното; и каде што нема особено силна разлика меѓу магиските моќи на луѓето и божествената моќ. Во обете функционира принципот дека сличното произведува слично. Џевонс, меѓутоа, резимира Мос, „...со најсилна енергија ѝ се спротивставува на оваа теорија“. ${ }^{9}$ Спротивно на тоа дека магијата е изворот на религијата или, пак, идентична со

\footnotetext{
${ }^{6}$ F. B. Jevons, Introduction to the History of Religions, Methuen, London, 1896, p. 15.

${ }^{7}$ F. B. Jevons, op. cit., p. 16.

${ }^{8}$ Првиот разлог за отфрлање е во разбирањето на снаоѓањето низ животот. Животните имаат вообичаени навики: кога одат да пијат вода, очекуваат дека таа ќе им ја згаси жедта и не се изненадуваат секој пат кога ќе им успее тоа. Погрешно е интелектот на примитивните луѓ да се редуцира на ниво пониско од она на животните, до ниво на кое се прашува и стравува дали водата ке му ја згасне жедта, а храната - гладот. Потоа, психолошки факт е вродената тенденција на човековиот ум да верува дека она што се случило еднаш ќе се случи повторно. Сѐ додека искуството не го коригира ова, едно случување е доволно да создаде очекување за повторување. Од ова може да се заклучи, смета тој, дека од почетокот постоеле секвенции на феномени, некакви закони кои биле опсервирани и чие случување било прашање на тек и на природност F. B. Jevons, op. cit., p. 18.

"M. Mauss, "L'école anthropologique anglaise et la théorie de la religion selon Jevons", Année sociologique 1, 1898, pp. 169 à 170, "Les classiques des sciences sociales", Université du Québec, 2002, p. 5.
} 
неа, Џевонс смета дека таа има сосема инакво потекло. Концепцијата на природата на Фрејзер во која луѓето и божествата сосема едноставно можат да се помешаат, „...каде што мешањето на натприродното и на природното ги снабдува фантазмогоричните поими со божествени и човечки дејства“" никогаш и не постоела. ${ }^{10}$ Наместо да ги има можните „каприци“ на природата како принцип, магијата на примордијалниот човек се базира на униформноста на нејзините закони. Анимизмот за Џевонс е научна теорија за нештата, а не само верување, онака како што симпатетичката магија е приемната наука на архаичниот човек. Според ова гледиште на Џевонс, примитивниот човек верува во ефикасноста на магијата затоа што со сигурност верува во постоењето на природни, униформни закони. Религијата, пак, има инакво потекло, таа се темели на верувањето во натприродни суштества, чие постоење се дедуцира од констатацијата на нешта и факти кои се надвор од досегот на моќите на човекот. Мос резимира - нужноста да се влезе во пријателски односи со ваквите инстанции, преку култот или религијата, потекнува оттаму. Религијата ја има за цел благосостојбата на заедницата, во неа се работи за обиди за помирување на натприродните суштества со светот на човекот. Уште од нејзиното прво појавување, религијата има вистинска алијанса меѓу натчовечките суштества и човекот, преку прифаќање и покорување на нивната моќ, со помош на ритуали на поврзување со нив, преку тотемизмот или преку инакви практики. ${ }^{11}$ Покрај тоа, Мос наведува дека Џевонс на ист начин ги разликува магијата и култот, свештеникот и божеството, тврдејќи дека нивната фузија е само секундарен феномен - во смисла на тоа дека кога магијата пенетрира во религијата, свештеникот само случајно станува божество. Тотемскиот култ на кој се фокусира Џевонс (а потоа и Диркем) се базира на симпатетичка магија - целиот клан е тотемот и обратно, со чинови на асимилација на тотемот. За преттотемските култови, пак, е невозможно да се говори, се воздржува Мос. Фактите што се достапни не се совпаѓаaт со сликата за потеклото на религијата која ја има формирано Џевонс. ${ }^{12}$

Проблемот во ставот на Џевонс, смета Диркем, е што натприродното не може да се редуцира на непредвиденото. Новото или неочекуваното, исто така, е дел од природата колку и нему спротивното. Ако се забележи дека, општо земено, настаните се случуваат според сукцесивен ред, исто така, се забележува дека тој ред е само приближен, не е секогаш ист во различни случаи, како и тоа дека има голем број исклучоци. Сведочењето на неочекувани настани не може да биде доволно за формирање идеја за натприродното. За да се постигне тоа, овие настани мора да бидат замислени како невозможни за помирување со ред што, точно или неточно, се смета за нужен ред на нештата. Покрај тоа, додава Диркем, како и да биле доживувани искуствата на нови нешта и случајни настани, тие концепции никако не можат да ја карактеризираат религијата. Религиските концепции не се стремат да го изразат и да го објаснат она што е чудесно и абнормално, туку она што е постојано и редовно. Се чини дека Џевонс би одговорил на ова дека ваквото сфаќање на религиозните

\footnotetext{
${ }^{10}$ Ibid.

${ }^{11}$ M. Mauss, op. cit., p. 6.

${ }^{12}$ M. Mauss, op. cit., p. 9.
} 
сили не е примитивно, затоа што луѓето прво ги употребувале за конципирање на нередот и случајностите, а дури подоцна за да ја објаснуваат униформноста на природата. ${ }^{13}$

Архаичниот човек, според Роберт Ранулф Марет (Robert Ranulf Marett), не бил филозоф каков што го прикажуваат неговите современици, теоретичари на религијата. Кај раниот човек идеите не ѝ даваат поттик на акцијата, туку акцијата им дава поттик на идеите - „...религијата не е нешто обмислено, туку нешто истанцувано (danced)“. ${ }^{14}$ Во најраните фази религијата не може сосема да се оддели од магијата, туку плаузибилно може да се зборува за магиско-религиски искуства на примордијалниот човек. ${ }^{15}$

Миметичките дејства во позитивниот култ

Позитивниот култ постои, според Диркем, благодарение на фактот што во религиските должности постои позитивен двостран однос меѓу верникот и светот, што мора да биде регулиран од збир на правила. Позитивниот култ е специфичниот систем на ритуални практики што го регулираат религиозното однесување пропишувајќ правила за однесување. Исполнувањето на позитивниот култ е мошне разновидно. Верување кое е карактеристично за потребата од исполнување на религиозните правила е она за

${ }_{13}^{13}$ Доколку се следи аргументацијата од F. В. Jevons, op. cit., p. 23.

${ }_{14}$ R. R. Marett, The Threshold of Religion, Methuen\&Co, London, 1914, хxхі). Обемна студија која го третира примордијалниот човек како филозоф е таа на Пол Редин (Paul Radin), во која го разгледува човекот низ неговите концепти за добро и лошо, правилно и неправилно, неговата филозофија на животот (судбината, смртта и помирувањето), трагичната смисла на животот, неговата систематизација на идеите, почетоците на поимот и идејата за Бог итн. (P. Radin, Primitive Man as Philosopher, D. Appleton \& Co, New York, 1927).

15 Во оваа смисла и се поставуваат прашањата за тоа дали верувањето во мана (аниматизмот) е верување во магиско дејство и дали, ако е така, маната, како подлежечка сила во светот што се екстериоризира низ разни ствари, појави и луѓе, може да се смета за „позитивна магија“, според што табуто, односно забранетиот аспект на маната, би било „негативна магија“. Идејата овде е дека може да се зборува за аналогно поврзување - доколку маната е симпатетичка магија, табуто е негативна магија. Концепцијата за позитивна и за негативна магија е прилично проблематична, сепак, особено што се меша со идеите за „бела“ и „црна“ магија, психолошки-фолклорно засилени, а теориски речиси неважни. И позитивното и негативното во магијата се арбитрарни определби (ниту се нужни во директна дијалектичка спрега) и, методолошки гледано, повеќе создаваат проблеми отколку што решаваат.

Бронисуав Малиновски (Bronisław Malinowski) постојано инсистира на тоа дека магијата не само што е типично човечка „сопственост“ туку е буквално во човекот и може да се пренесува само од човек на човек, според строгите правила на магиски поврзувања, иницијации и учење. Никогаш не се замислува како природна сила што постои во нештата надвор од човекот, што дејствува независно, што треба да биде откриена и научена. Затоа, според Малиновски, сите теории што го поставуваат верувањето во мана како основа на магијата одат во погрешна насока. Затоа што, ако вредноста на магијата е локализирана токму во човекот (и само во него), и од него може да се „извади“ преку традиционални строги правила, секако не е силата што истражувачите на маната (Роберт X. Кодрингтон како првиот кој сериозно ѝ обрнал внимание, на пример, со неговото дело R. H. Codrington, The Melanesians - Studies in Their Anthropology and Folkore, Clarendon Press, Oxford, 1891) ја определуваат како наперсонална сила што може да се екстериоризира низ речиси што било, дејствувајки за добро или зло, и покажувајќи се како моќ или преобилност на доблест, успех и слично. Вистинската вредност на магијата, се повикува Малиновски на наоди од Меланезија исто како и аниматистите, е фиксирана само во магиското искажување и дејствување, и се екстериоризира преку строго дефинирани процедури и места. За разлика од маната, што дејствува на кој било начин, магијата дејствува само на начини определени од традицијата, никогаш покажувајќ се како недефинирана физичка сила, а имајќи ефекти врз моќите и способностите на човекот, што се строго лимитирани и дефинирани (В. Malinowski, Magic. Science and Religion, The Free Press, Glencoe, 1948, p. 5657). 
иницијалната светост на светот, односно за сеќавањето на светите, митски предци на клановите. Идејата за светиот тотем е токму во верувањето дека постои идентитет меѓу индивидуата и нејзиниот тотем. Важно е тоа што за верникот ефикасноста на ритуалите што ги извршува е несомнена. Тој е убеден дека тие мора да ги произведат очекуваните резултати, дури со идеја за нужност. Ефикасноста на ритуалите може да се „поништи“ од исто толку силна контрамоќ (злите дела на непријателска заедница, на пример). Важноста на повикувањето на митската светост и на моќта на ритуалот е толку голема што за поволните исходи не се бараат никакви други причини. Ако се добие посакуваниот ефект пред ритуалот воопшто да биде завршен, тоа се припишува на силата на претходно направен ритуал, или на можноста душите на предците да се имаат „погрижено“ за добивањето на посакуваното. ${ }^{16}$ Ритуалите кои преку имитирање на различните звуци што ги произведува тотемското животно или преку подражавање на различните начини на кои се однесува, наречени уште мимейички ритуали, служат за осигурување на репродукцијата на животното кое се подражава. На тој начин симболиката на семето за плодноста на видот преку светите камења, прашина или симболични фертилизации на земјата се дополнува со мимезис на тотемскиот вид. Може да се каже дека, доколку се следи линијата на форсирање на магијата на Фрејзер, за сите овие ритуали е карактеристично тоа што принципот на кој се потпираат е функционирањето на симпатетичката магија. Според Диркем, тој принцип „...често, но некоректно, се нарекува симйайейичка маїија“. ${ }^{17}$

Миметичките ритуали не се однесуваат само на животниски видови, туку и на растителни, а и на атмосферски појави. Фрејзер ја истражува магиската контрола на времето - миметичките ритуали за контролата на дождот, за неговото повикување и запирање. Ритуалната практика е многу покомплицирана од само имитирање на звукот на дождот или ритуалеми што инволвираат истурање на вода и претставување на богата вегетација; симболично исушување на мали водени површини итн., но елементот на мимезис е присутен во повеќето. Карактеристичен пример што го дава Фрејзер е оној за ритуалот на додоле во Македонија и во Србија, во кој се повикува обилен дожд преку процесија на претставување на дрвја во раст, растење на тревата и истурање на кобли вода. ${ }^{18}$ Контролата на ветрот е во многу случаи во врска со контролата на дождот, затоа што вообичаено се појавуваат заедно во разни типови бури. За влијанието врз ветрот има посебни магиски ритуали на имитирање на неговите звуци, разорна или благонаклона моќ и слично. ${ }^{19}$ Магиската контрола на сонцето во некои заедници подразбира ритуали за одржување на „животот“ на сонцето за време на еквинокс, преку специјални повторувани ритуали меѓу

${ }^{16}$ É. Durkheim, op. cit., p. 475. Ова значи дека „неочекуваните“ исходи не се вистински неочекувани, затоа што моќта и „планот“ на светото (на маната, на предците, на душите или духовите, на божеството) не му се познати на верникот. Тој безусловно верува во силата на ритуалот и благодатноста на контактот со светото. На овој начин можат да се третираат и чудата - пројавувањето на светото на специфичен, непретходен, необичен и необјаснив начин, за верникот не е чудно. Иманентно земено, верникот е верник затоа што не ја реиспитува моќта на она во кое верува. Според тоа, не би требало да се зборува токму за „чуда“ во релацијата на верникот кон необјаснивата моќ на светото (независно дали е конципирано според она што го означуваат грчките зборови dinamis или, пак, thavma).

${ }^{17}$ É. Durkheim, op. cit., p. 508.

${ }_{18}^{18}$ J. Frazer, op. cit., pp. 153-178.

${ }^{19}$ J. Frazer, op. cit., pp. 193-199. 
еквинокс и зимскиот солстициј. Исто така, карактеристично е поврзувањето на сонцето со огнот, разгорувањето на огнот како симболичен чин на силното греење на сонцето, односно гаснењето на огнот како претстава на заоѓањето на сонцето, или намалување на неговиот интензитет. $^{20}$

Ендрју Ланг (Andrrew Lang) во својата критика на разбирањето на менталната состојба на примитивните луѓе го подвлекува специфичното верување во способноста за контрола на времето - на ветрот, на дождот и на обилноста на изворите во голема мера преку миметички изведби како типично за примордијалната ритуалност. ${ }^{21}$ Малиновски потсетува дека магијата не е типично човечка само во нејзиното втеловување, туку и во нејзиниот предмет: таа не е несочена толку кон природата колку кон односот на човекот кон природата, и неговите дејства што ѝ влијаат. И, уште повеќе, резултатите на магијата вообичаено се конципираат не како производ на природата на која магиското дејство ѝ влијаело, туку како нешто специфично магиско, нешто што не може да го произведе природата, туку може само моќта на магијата. ${ }^{22}$

Двата основни принципа на симпатетичката магија, оној на сличноста и оној на контактот, можат да се сведат на верувањето дека сличното произведува слично, односно дека претставувањето на некакво суштество или состојба ги произведува тоа суштество или состојба. Се работи за верувањето дека контакт со објектот подразбира и контакт со сето она кое на тој објект му е блиско на каков било начин, односно дека ако кое било х било во контакт со у, (дел од) х продолжува да биде во контакт со сето она што претставува у. Или, како што го формулира Фрејзер, „сличното произведува слично, односно последицата е слична на причината; нештата кои еднаш биле во контакт продолжуваат да влијаат едни врз други и по прекинувањето на контактот [...], првиот принцип е законот на сличноста, а вториот закон на контакт или контагиозност. ${ }^{23}$ Следејќ го првиот принцип, односно законот на сличност, во магијата се верува дека може да се произведе последица преку мимезис на таа последица, а според вториот принцип - на контакт, се заклучува дека какво било влијание на материјален објект влијае и на оној со кој тој објект некогаш бил во контакт. Така, магијата базирана на принципот на сличност е хомеопатска или имитативна, а онаа базирана на законот на контакт или контагион - контагиозна магија. Изразот хомеойайска маіија Фрејзер му го должи на И. Хирн (Y. Hirn), ${ }^{24}$ претпочитајќи го наместо предлогот имитиайивна или миметиччка маіија на Сидни Харланд (Sidney Harland), затоа што смета дека тие изрази сугерираат свесен дејствувател кој имитира, со што целта на магијата многу се стеснува - магот претпоставува дека принципите по кои дејствува се универзални. Фрејзер уште прави поделба и на теоретска и практична магија: теоретска е онаа која е систем на природни закони, односно израз на правила што ги определуваат секвенциите на настани во светот, а практична е онаа која е збир на правила за однесување

\footnotetext{
${ }^{20}$ J. Frazer, op. cit., pp. 170-192, J. Frazer, Lectures on the Early History of the Kingship, Macmillan, London-New York, 1905, pp. 93-107.

${ }^{21}$ A. Lang, Myth, Ritual and Religion, Longmans, London, 1884, I, 2, 1.

${ }^{22}$ B. Malinowski, op. cit., p. 56.

${ }^{23}$ J. Frazer, Lectures on the Early History of the Kingship, p. 37

${ }^{24}$ Според Ү. Hirn, Origins of Art, London, 1900, p. 282.
} 
што треба да се следат за да се дојде до посакувани цели. ${ }^{25}$ Обата принципа на симпатетичката магија, како збир на хомеопатската и контагиозната, беше покажано, за Фрејзер се два вида погрешна примена на законот на асоцијација на идеи - во хомеопатската магија асоцијацијата на идеи по сличност, а во контагиозната според континуитет. Сосема едноставно - грешката на хомеопатската магија е во претпоставката дека сличните нешта се исти нешта, а на контагиозната магија дека нештата кои еднаш биле во контакт, секогаш остануваат во контакт. Двата вида магија се комплементарни, со тоа што додека хомеопатската или имитативната магија може да се применува сама, контагиозната магија, општо земено, опфаќа и принципи на хомеопатската. Идејата за симпатетичка магија Фрејзер ја темели на претпоставката дека магијата функционира преку принцип на тајна симпатија, односно импулс што се пренесува од едно на друго нешто низ некаков недефиниран ,етер“, слично на претпоставката во науката од почетокот на XX век дека етерот е празен простор низ кој нештата физички влијаат едни на други. ${ }^{26}$

Мос и Анри Убер (Henri Hubert) сметаат дека магиските техники, дејствата што ги вклучуваат и резултатите што ги очекуваат остануваат присутни во современиот живот. Медицината и алхемијата, на пример, долго време функционирале со техничкиот елемент колку што е можно редуциран, а темелејќи се на доминантни магиски концепции. Медицинскиот чин речиси до почетокот на XX век е придружен со религиозни и магиски прескрипции, а и останува придружен со магиски посакувања, молитви, опсесивнокомпулсивна претпазливост. Лекарствата, специјалниот режим на исхрана препишан од лекарот, техниката на хирургот и слично, се вистинско ткиво на симболизми, симпатии, хомеопатии, антипатии - всушност, едноставно кажано, можат да бидат замислени како магиски. Ефикасноста на ритуалот и на вештината (во смисла на ars или tehne) не се сосема разлачени, туку се замислуваат истовремено. ${ }^{27}$ Дури, забележуваат Мос и Убер, можеби нема подрачје на нашите цели што се достигнуваат преку индустриските и произведувачките вештини, што не е на некој начин сѐ уште обележано со магија. Критериумите за разликување на религиозен од магиски чин предложени од Фрејзер им се чинат недоволни. Определувањето на магијата како симпатетички ритуал е несоодветно, затоа што постојат магиски ритуали кои не се симпатетички, а симпатијата е карактеристична за религијата општо. Вториот критериум - дека магискиот ритуал дејствува сам по себе, за разлика од религискиот, односно дека првиот има директно механичко дејство, а вториот дејствува индиректно преку вид на почитувачко убедување, преку духовно посредништво, е несоодветен. Религискиот ритуал, како и магискиот, исто така, често ѝ пркоси на стварноста само по себе. Покрај тоа, не е точно дека сите магиски ритуали имаат директно дејство - и во магијата се манипулира со духови или се повикува на божества, значи, исто така, важи и правилото на можно духовно посредништво. Ниту, пак, оној на кого му се насочени дејствата во магијата секогаш ги исполнува барањата. ${ }^{28}$

\footnotetext{
${ }^{25}$ J. Frazer, op. cit., p. 38.

${ }^{26}$ J. Frazer, op. cit., pp. 38-40.

${ }^{27}$ M. Mauss, H. Hubert, „Esquisse d'une théorie générale de la magie“,Année Sociologique, 1902-1903, "Les classiques des sciences sociales", Université du Québec à Chicoutimi, 2002, p. 11.

${ }^{28}$ M. Mauss, H. Hubert, op. cit., pp. 12-13.
} 
За Фрејзер, голем број ритуали на австралиските племиња се магиски, токму поради интензивната употреба на симпатетички врски. Според Мос и Убер и Диркем, свечените, јавни, задолжителни, редовни церемонии, како што се прослави и сакраменти, ја имаат важноста, значајноста и светоста карактеристична за религијата, не за магијата, иако механизмите, некогаш и доминантно, им се симпатетички. За Мос и Убер типично магиски ритуали се проколнувачките, кои во религијата и во обичајното право се често експлицитно забранувани и казнувани. Во овие случаи на осудување на проколнувачките, штетни ритуализации на жрецот, во забраната за примена на магиските механизми за штетни цели, Мос и Убер гледаат формално дефиниран антагонизам меѓу магискиот и религиозниот ритуал.

Наштетувачкиот и проколнувачкиот пол на магијата може да се спротивстави на жртвувачкиот пол на религијата. Така, додека религијата, генерално, е насочена кон определен идеал кон кој се стремат химните, желбите, жртвите и кој го штитат системите на забрани, магијата ги одбегнува тие категории. Меѓу двата пола постои конфузна територија која ги опфаќа практиките кои не се ниту забрани ниту специфични правила, како и религиозните чинови кои се индивидуални (повремените чинови на култот на индивидуата) и опциони и магиските чинови кои се задолжителни (магиски практики асоцирани со техники од други сфери, како што се, на пример, медицинските). Магијата може да се смета за вид религија за задоволување на инфериорните потреби на домашниот живот. ${ }^{29}$

За Мос и Убер, точно е дека магијата личи на огромна варијација на темата на принципот на каузалитетот, но, исто така, е точно дека тоа ништо не кажува за магијата, затоа што нејзина главна цел е произведувањето последици од причини. Со внимателно симплифицирање на нејзините формули, невозможно е таа да не се разгледува како вид научна дисциплина, како примитивна наука, што, впрочем, го прават Фрејзер и Џевонс. Мос и Убер додаваат дека „...магијата ја врши функцијата на наука, и го чува местото на науките кои допрва треба да се родат“. 30

Во симпатетичката магија Мос и Убер определуваат три доминантни закони: законот на континуитет, на сличност и на контраст. Според овие закони, нештата кои некогаш биле во контакт остануваат поврзани, сличното го произведува сличното и спротивното дејствува врз спротивното, соодветно. Или, може да се смета дека формулите на континуитет, сличност и спротивност важат како формули на симултаност, идентитет и опозиција, во мисла и во факт. Законот на континуитетот, според неговата наједноставна форма, е изразен преку идентификацијата на делот со целината. ${ }^{31}$ Во првиот случај се очекува прво отсуство на некаква состојба, во вториот случај се очекува прво присуство на некаква состојба, а во третиот се очекува присуство на состојба спротивна на состојбата која треба да се произведе. ${ }^{32}$

Одделувањето на делот од целината не го прекинува нивниот континуитет, нешто може да се реконструира или реоживее само преку помош на еден негов дел (totum ex parte).

\footnotetext{
${ }^{29}$ M. Mauss, H. Hubert, op. cit., p. 13.

${ }^{30}$ M. Mauss, H. Hubert, op. cit., p. 44.

${ }^{31}$ Ibid.

${ }^{32}$ M. Mauss, H. Hubert, op. cit., p. 50.
} 
Идејата е дека секој објект интегрално го опфаќа суштинскиот принцип на видот на кој му припаѓa. Идејата на контагион е имплицирана во идеајта за магискиот континуитет. ${ }^{33}$

Вториот закон, или законот на сличноста, е помалку директен израз на симпатетичките релации од првиот ${ }^{34}$ и има две главни формули: 1. сличното го предизвикува сличното (similia similibus evocantur) и 2. сличното дејствува врз сличното во специфична релации на лечење, т.е. сличното го лечи сличното (similia similibus curantur). ${ }^{35}$ Според првата формула, сличноста важи како континуитет. Сликата за стварта е она кое делот е за целината. Едноставна фигура е надвор од каков било контакт и каква било директна комуникација, интегрално репрезентативна. Но, сликата и она кое го претставува немаат ништо заедничко освен конвенционалната сличност која ги поврзува. Сликата, претставата на стварта, е само сосема редуцирана шема или деформиран идеограм, таа е слична само теоретски или апстрактно. Сликата се дефинира само преку нејзината функција, а тоа е да го повика присуството на стварта (или личноста) која ја претставува, преку конвенционалната врска на сличност меѓу нив. Основно е, значи, да се исполни функцијата на репрезентација. Поимот на сликата, доколку се прошири, станува поим на симболот. Посакуваните појави, дејства, нешта, можат да се претстават симболички преку нивните симболични претстави. Ова, секако, повлекува и проблеми на интерпретација избраните симболи се толкуваат според нивните очекувани функции, кои се вршат преку симболите, а со интервенција на оној што ги изведува магиските дејства. Интересно е тоа што од објектите што ги одбираат за симболи маговите задржуваат по една карактеристика. Значи, тие не само што ги одбираат симболите и ја диктираат нивната употреба, туку и ги лимитираат консеквенциите на дејствата, кои, теоретски, како сериите на асоцијација по континуитет, би требало да бидат неограничени. Покрај тоа, сите квалитети на симболот не се пренесуваат на симболизираното. Втората формула, според која сличното го лечи сличното, се разликува од првата во тоа што додека првата се однесува на општото предизвикување на последици, втората се однесува на тоа дека асимилацијата произведува последица со определена насока. ${ }^{36}$ Без да се излегува од оваа форма на законот на сличноста, се доаѓ до идејата за спротивноста. Впрочем, кога сличното го лечи сличното, тоа кое се произведува е спротивно. Значи, точната формула би била: сличното воведува слично за да го предизвика спротивното. Дури и во првите видови миметичка симпатија може да се најде овој механизам - кога на земјата се истура вода за да се предизвика дожд, тој, како сличен на водата, се повикува преку уништување на сувото на земјата, во функција на уништување на сушата. Формулите би можеле да се спојат во принципот дека спротивното го истиснува спротивното. Ова покажува до колкав степен апстрактниот поим на сличноста е неразделен од поимот на спротивноста, и тоа не само затоа што се логички поврзана дихотомија. Сепак, општиот впечаток од етнолошките истражувања е дека законот за спротивноста се третира како посебен. Симпатиите се еквивалентни на антипатиите, само

\footnotetext{
${ }^{33}$ M. Mauss, H. Hubert, op. cit., p. 45.

${ }^{34}$ Во оваа смисла, коректно е што Фрејзер и Сидни Хартланд името симйайија во полна смисла го ограничуваат на феномените на контагионот, а мимейичка симйайија го даваат на она кое Мос и Убер го определуваат за йринцийи на сличносй.

${ }^{35}$ M. Mauss, H. Hubert, op. cit., p. 47.

${ }^{36}$ M. Mauss, H. Hubert, op. cit., pp. 48-50.
} 
со различен предзнак, а сепак не може да се тврди дека не се јасно дистинктни. Целата магија може да се изрази низ парови на спротивности: среќа и несреќа; слобода и неслобода; фертилност и нефертилност и слично. ${ }^{37}$

Принципот на каузалност во симпатетичката магија нема само ритуална функција, туку е од директна важност за теоријата на познание, затоа што е една е најраните формулации на законот на каузалност, смета Диркем. Во принципот дека сличното произведува слично е содржан полн поим на каузална релација. Преку магиските техники и како основа на практиките на култот, се работи за концепција типична за примордијалната мисла. $^{38}$ Основното во врска со идејата за каузалните релации е што се имплицира ефикасност, ефективна моќ или сила. Според Диркем, под йричина вообичаено се подразбира она кое е способно да предизвика детерминирана промена. Односно, причината е силата пред да ја манифестира моќта која ја содржи. Последицата, според тоа, е истата таа моќ, но актуализирана. Каузалноста, односно идејата за каузалноста, за Диркем има социјални причини, таа е потребна и екстериоризирана во социјален контекст. Основна карактеристика на неперсоналните сили е тоа што се пренесуваат од еден на друг објект и од една на друга појава, мешајќи се и комбинирајќи се едни со други и трансформирајќи се едни во други. Ваквата способност им дава објаснувачка вредност. Преку ова својство, последиците се спојуваат со нивните причини без дисконтинуитет. „Јас“, меѓутоа, е потполно спротивно по природа, тоа не може да биде пренесено, а се шири и трансформира само во метафоричка смисла. Затоа, според Диркем, идејата за силата мора да има двоен карактер: прво, може да дојде само како внатрешно искуство, затоа што единствените сили кои директно ги доживуваме се нужно морални сили; а истовремено, таквите сили мора да се и неперсонални, затоа што примарна е идејата за неперсонална сила. Според Диркем, емпиризмот не успеал да ги објасни априоризмот и нужноста, затоа што „...филозофите од таа школа не биле способни да објаснат како асоцијација на идеите засилена од навиката може да произведе што било повеќе од состојба на очекување“. ${ }^{39}$ Принципот на каузалност има сосема различен карактер, затоа што не е само инхерентна тенденција на мислата да се движи на определен начин, туку е надворешна и супериорна норма на текот на човековите претстави, која ги води и ги регулира апсолутно, преку авторитет кој го врзува интелектот и оди отаде него. Но, природата на навиката не се менува затоа што трае подолго од животот на човекот, тоа само значи дека трае подолго. Инстинктот не е правило. Всушност, се чини дека она што на Диркем му пречи во каузалноста истражувана од емпиризмот е што општествените и религиозните релации не биле земени предвид. Ритуалите што ги истражуваат етнографите и на кои тој прави анализа и метаанализа му овозможуваат да

\footnotetext{
${ }^{37}$ M. Mauss, H. Hubert, op. cit., p. 51.

${ }^{38}$ É. Durkheim, op. cit., p. 518.

${ }^{39}$ É. Durkheim, op. cit., p. 524. Сепак, идејата на емпиристите, особено на Дејвид Хјум (David Hume), токму не е да покажат како асоцијацијата на идеите, заедно со навиката и обичајот можат да предизвикаат познание на нужна врска и очекување на вистинитост, напротив, недостатокот на нужна врска меѓу причините и последиците е она кое е проблематично. Се добива впечаток дека Диркем смета дека социолошки пристап би го помирил недоразбирањето околу емпириското потекло на познавателните категории, како сфаќњето на причинскопоследичните релации. Сепак, не се чини дека Диркем дава јасна основа за концептот на каузалноста во директното искуство на социјалните механизми и процеси.
} 
види нова страна на каузалните закони. ${ }^{40}$ Идеите за причинско-последичните релации во миметичките ритуали се јавуваат кога групата се собира со една грижа: ако видот чие име и суштина кланот го носи не се размножи, кланот и сета негова средина се осудени на пропаст. Навиката и заедничкото чувство кое доминираат се изразуваат низ лимитираната форма на определени активности кои секогаш се повторуваат во исти периоди и со исти околности; и секогаш се чини дека посакуваниот резултат се добива откако успешно ќе се изведат тие определени церемонии. Затоа се јавува јасна врска меѓу идејата за добиениот резултат и дејствата што му претходат (доколку не се јави резулатот, се споделува колективната состојба на очекување). Причинско-последичните односи од егзистенцијален тип се задолжителни. Принципи од типот на тој дека сличното произведува слично не се нешто во кое се сомнева, тие се земаат како аксиоми. ${ }^{41}$

Една од главните карактеристики на религијата е што не зависи од информациите од искуството. Периодичните неуспеси на ритуалите не ја разнишуваат верата во нивната моќ. Повторувачките религиски практики не можат да бидат ставени под сомнение без да се разниша целата суштина на религиозниот човек кој верува во нив, која дава отпор. Но, колку и да се противи религиозниот менталитет, тоа не го разликува многу од други форми на човечки менталитет, дури и од оние што вообичаено му се спротивставуваат. Во оваа смисла, Диркем лоцира само разлика во степен меѓу менталитетот на примордијалниот верник и на современиот научник. Во искуство во кое еден научен закон има авторитет добиен од многубројни успешни експерименти, повтроливност и применливост, неговото отфрлање само затоа што се појавил еден факт што му противречи е спротивно на целиот метод. ${ }^{42}$ Неуспешниот ритуал за примордијалниот верник е уште помалку контрадикторен на искуството, затоа што неговата вредност се потпира на поголем број факти што одат заедно со него. Додека магијата за Фрејзер е примарна, а религијата е еден вид нејзин дериват, за Диркем правилата на кои се фундирани техниките на магот се формирани под

\footnotetext{
${ }^{40}$ Каузалноста може да биде објаснета преку Кантовата идеја дека е вродена или, пак, дека е некаков инстинкт или, според Хјум, мислење. Сосема симплифицирано, за прагматизмот развиен десетина години пред аргументацијата во Елеменйарнийе форми на релиіиозниой живой, иако каузалноста како концепт може и да нема емпириска валидност, сепак, таа има доволна искуствена база за фундирање на прагматичка валидност, односно вистина според конвенција. Диркем не го лоцира потеклото на фундаменталните категории на човековата мисла, или разум, во индивидуалната перцепција, ниту како вроден аспект на умот, туку во споделеното емоционално искуство на ритуално произведените морални сили, кои произлегуваат од изведувањето конкретни практики во рамки на заедницата. Со ова, се чини, дивергира од постоечките алтернативи на неговото време. Според Ен Уорфилд-Ролс (Ann Warfield-Rawls) Диркем го „...третира прашањето за потеклото на идејата за светото, првиот израз на морална сила, како клуч за функционирачки, емпириски основан епистемолошки аргумент“ (A. Warfield Rawls, Epistemology and Practice Durkheim 's The Elementary Forms of Religious Life, Cambridge University Press, Cambridge, 2005 , p. 29). Во нејзината анализа на епистемолошкиот проект на Диркем, таа смета дека тој е многу попосветен на проблемот на каузалност отколку што се чини (A. Warfield-Rawls, op. cit., p. 229).

${ }^{41}$ Прашање е зошто Диркем мисли дека ваквата анализа го разјаснува проблемот подобро од емпиризмот, но се чини дека е уверен во својата успешност.

42 Овој став на Диркем е малку проблематичен. Целта на науката е стремежот, ако не кон максимална јасност и докажаност, тогаш кон минимална нејасност и недокажаност. Појавата на експлицитно контрадикторни факти, секако, претставува проблем. Ова е речиси како да се каже дека исклучокот го потврдува правилото. Сѐ што може да направи исклучокот е да го разниша или поништи правилото, никако да го потврди.
} 
влијание на чисто религиозни идеи, а потоа, по секундарна екстензија, се трансформирани во дејства со секуларна примена.

Миметичките ритуали и понатаму постојат во доминантните сложени монотеистички системи. Принципот на сличност, односно хомеопатската магија, има пролиферирано во практикувањето на хомеопатска медицина. Верувањето во нашата доминација врз природата, исто така, се одржува, и понатаму ставајќи го акцентот врз нашите моќи да интервенираме врз стварноста, но и врз нашето уверување дека сме зависни од неа во принцип на двојна спрега. Посветеноста на нешто и грижата за нешто (религискиот објект) специфични за религијата во магијата се претставуваат како верување во моќта на нешто и манифестирање на моќта врз тоа нешто. Во светот на вртоглаво развивачка технологија и растечка потребата од разбирање на нас како дел од тоталитетот, се чини, се важни обата пристапа. 


\section{Литерапура}

Codrington, R. H., The Melanesians - Studies in Their Anthropology and Folkore, Clarendon Press, Oxford, 1891

Durkheim, E., Les formes élémentaires de la vie religieuse, PUF, Paris, 1968.

Frazer, J. G., The Golden Bough: A Study in Magic and Religion (Electronic version Wordwordth, London, 1890), The Floating Press, 2009.

Frazer, J. G., Lectures on the Early History of the Kingship, Macmillan, London-New York, 1905.

Jevons, F. B., Introduction to the History of Religions, Methuen, London, 1896.

Lang, A., Myth, Ritual and Religion, Longmans, London, 1884,

Malinowski, B., Magic, Science and Religion, The Free Press, Glencoe, 1948.

Marett, R. R., The Threshold of Religion, Methuen\&Co, London, 1914.

Mauss, M., "L'école anthropologique anglaise et la théorie de la religion selon Jevons", Année sociologique 1, 1898, pp. 169 à 170, "Les classiques des sciences sociales", Université du Québec, 2002.

Mauss, M., Hubert, H., „Esquisse d'une théorie générale de la magie“,Année Sociologique, 19021903, "Les classiques des sciences sociales", Université du Québec à Chicoutimi, 2002.

Radin, P., Primitive Man as Philosopher, D. Appleton \& Co, New York, 1927.

Tylor, E. B. Primitive Culture (Researches Into whe Development of Mythology, Philosophy, Religion, Language, Art and Custom), Vol. II, Henry Holt and Company, New York 1874.

Warfield Rawls, A., Epistemology and Practice Durkheim's the Elementary Forms of Religious Life, Cambridge University Press, Cambridge, 2005. 
Marija TODOROVSKA

\section{THE PRCINCIPLES OF MAGIC IN THE UNDERSTANDING OF THE ORIGIN OF} RELIGION

\section{Summary}

The concepts of "natural" and "supernatural" in the primordial understanding of reality are shown through the points of view of classical authors in the field of the theories on the origin and on the nature of religion (Tylor, Frazer, Durkheim, Jevons etc.). The grasp of (super)natural forces and the belief in some ontologically dominant existence by the archaic religious men are then outlined in the principles through which their beliefs about their relation with and their position in the world can be summed up. The ideas that homo religious, through a series of ritual acts, thoroughly planned and meticulously controlled, has the capacity to establish a functioning and fruitful relationship with the (super)natural force(s) dominating his world are in the basis of the belief in magic, and also partially of the early forms of religion. The series of magical mimetic actions within the positive cult are outlined through the summaries of Frazer and Mauss and Hubert, and through the similarities and differences between their definitions of the principles of magic.

Keywords: MAGIC, (SUPER)NATURAL, RELIGIOUS MAN, RITUAL, PRINCIPLE 